\title{
Waterhouse Friderichsen Syndrome Report of Two Cases
}

\author{
Luis Del Carpio-Orantes ${ }^{1^{*}}$ (D), Jesús Salvador Sánchez-Díaz², Karla Gabriela-Peniche Moguel, Elisa \\ Estefania Aparicio-Sánchez ${ }^{1}$, Orlando Israel Segura-Rodríguez ${ }^{1}$, Andrés Aguilar-Silva ${ }^{1}$, Omar García- \\ Hernández ${ }^{1}$, Alejandro Escobar-Huerta ${ }^{1}$, Azael Ahumada-Zamudio ${ }^{1}$, Andrés Realino Velasco-Caicero ${ }^{1}$, \\ Olga González Segovia ${ }^{1}$ and Ernesto Javier Pacheco-Perez ${ }^{1}$
}

\author{
${ }^{1}$ Department of Internal Medicine, General Hospital 71, Veracruz North Delegation, Instituto Mexicano \\ del Seguro Social, Mexico \\ ${ }^{2}$ Intensive Care Unit, Specialty Hospital 14, Veracruz North Delegation, Instituto Mexicano del Seguro \\ Social, Mexico
}

\section{Waterhouse Friderichsen Syndrome}

This syndrome is characterized by necrohemorrhage of the adrenal glands in the course of a serious infectious disease, which is characterized by septic shock with multiple organ failure (prevailing neurological, renal and hematological failure even with criteria for disseminated intravascular coagulation), disseminated purpura and data on acute adrenal insufficiency. Initially described by an English physician in 1911, Dr. Rupert Waterhouse and later studied further by a Danish pediatrician, Dr. Carl Friderichsen in 1917 [1-3].

Within the etiology, it is mentioned that more than $90 \%$ of the cases are due to infectious agents, the rest to hematological pathologies or to certain added drugs. Of the infectious agents, Neisseria meningitidis is mentioned as responsible for $75-80 \%$ of the cases, the rest is distributed in a wide range of bacterial and rarely viral agents. In immunocompromised patients, the cases associated with cytomegalovirus that are hungry for the adrenal glands stand out. In a series of 5 postmortem cases, the presence of coagulase negative staphylococci was evidenced [1,4-7].

\section{Risk Factor's}

The main risk factors are: Immunosuppression, anatomical or functional asplenia/hyposplenia states (mainly congenital asplenia and that associated with thalassemia and sickle cell anemia), in patients who have not received the appropriate specific prophylaxis against pneumococci, meningococci and haemophilus influenza $[1,8,9]$.

\section{Diagnosis}

The initial clinical diagnosis is sudden and persistent high fever, associated with a picture of severe sepsis, the presence of rapidly progressive purpura, as well as evidence of adrenal insufficiency.

The biochemical findings demonstrate consumption coagulopathy fulfilling criteria for DIC (platelet penia, prolonged clotting times, dysfibrinogenemia and elevation of D-dimer), renal, hepatic, metabolic, respiratory lesions of varying magnitude. Likewise, you can find leukocytosis, normal leukocytes, or even leukopenia. It is important to emphasize the importance of taking diverse cultures in order to identify the etiological agent. We can use serum procalcitonin as a marker of bacterial sepsis. To rule out the presence of meningococci that usually affect predominantly at the neurological level initially, CSF analysis including culture is recommended, as well as detection of meningococcal antigens in various biological fluids and polymerase chain reaction, which helps to identify specific serogroups without requiring the presence of live microorganisms.

The confirmation of the diagnosis is made with imaging studies that demonstrate an adrenal hemorrhagic lesion or often during a necropsy, in cases where only in this last way they are diagnosed, going unnoticed $[3,10]$.

\section{Treatment}

The two main aspects to take into account are the start of broad-spectrum or specific antimicrobial therapy, which covers the most frequent possibilities, mainly meningococcus and gram-positive cocci, using penicillins, cephalosporins, glycopeptides and carbapenems; and on the other hand, start treatment of the shock state, always taking into account adrenal insufficiency, which will also require energetic fluid resuscitation, use of vasopressor amines, use of steroids such as fludrocortisone or hydrocortisone at stress doses, although

*Corresponding author: Dr. Luis del Carpio Orantes, Department of Internal Medicine, General Hospital 71, Veracruz North Delegation, Instituto Mexicano del Seguro Social, Mexico, Tel: 012292237932

Accepted: December 07, 2020

Published online: December 09, 2020

Citation: Carpio-Orantes LD, Sánchez-Díaz JS, Moguel KGP, et al. (2020) Waterhouse Friderichsen Syndrome Report of Two Cases. Dermatol Arch 4(1):99-101 
Citation: Carpio-Orantes LD, Sánchez-Díaz JS, Moguel KGP, et al. (2020) Waterhouse Friderichsen Syndrome Report of Two Cases. Dermatol Arch 4(1):99-101

Table 1: Two cases are presented in young, apparently healthy patients, who presented with disseminated purpuric symptoms and multiple organ failure that led to death, confirming the presence of Waterhouse Friderichsen syndrome due to adrenal involvement (Figure 1 and Figure 2).

\begin{tabular}{|c|c|c|}
\hline & Case 1 & Case 2 \\
\hline Genre, age & Female, 24-years-old & Male, 42-years-old \\
\hline Medical history & Apparently healthy & Apparently healthy \\
\hline Symptoms & $\begin{array}{l}\text { Fever, vomiting, disorientation } \\
\text { Purple spread } 12 \text { hours later }\end{array}$ & $\begin{array}{l}\text { Fever, disorientation, anuric } \\
\text { Purple spread } 6 \text { hours later }\end{array}$ \\
\hline Initial evaluation & $\begin{array}{l}\text { Deep shock }(80 / 40 \mathrm{mmHg}) \text {, metabolic acidosis, } \\
\text { multiple organ failure including adrenal and } \\
\text { respiratory failure. }\end{array}$ & $\begin{array}{l}\text { Deep shock }(88 / 53 \mathrm{mmHg}) \text {, metabolic acidosis, } \\
\text { multiple organ failure including adrenal and } \\
\text { respiratory failure. }\end{array}$ \\
\hline Hemoglobin & $12.6 \mathrm{~g}$ & $13.2 \mathrm{~g}$ \\
\hline Leukocytes & 9,800 & 31,900 \\
\hline Platelets & 43,000 & 15,000 \\
\hline Creatinine & $2.3 \mathrm{mg}$ & $6.0 \mathrm{mg}$ \\
\hline Creatine phosphokinase & $5,000 \mathrm{U}$ & $4,000 \mathrm{U}$ \\
\hline Bilirubins & $1.0 \mathrm{mg} / \mathrm{dl}$ & $2.2 \mathrm{mg} / \mathrm{dl}$ \\
\hline Transaminases & $65 / 70 \mathrm{U}$ & $120 / 178 \mathrm{U}$ \\
\hline Lactic dehydrogenase & $816 \mathrm{U}$ & $980 \mathrm{U}$ \\
\hline $\mathrm{Na} / \mathrm{K}$ & $132 / 3.2 \mathrm{mmol}$ & $128 / 4.5 \mathrm{mmol}$ \\
\hline Prothrombin time & does not coagulate & $32.6 \mathrm{seg}$ \\
\hline Partial thromboplastin time & $78.4 \mathrm{seg}$ & $42.6 \mathrm{seg}$ \\
\hline Fibrinogen & does not coagulate & $480 \mathrm{mg}$ \\
\hline $\mathrm{pH}, \mathrm{pO}_{2}, \mathrm{pCO}_{2}, \mathrm{HCO}_{3}$ & $7.06,87,37,10.1$ & $6.8,78,40,8.2$ \\
\hline Isolated pathogen & Staphylococcus haemolyticus & None \\
\hline Adrenal imaging & Adrenal necrosis & Adrenal necrosis \\
\hline Evolution and prognosis & $\begin{array}{l}\text { Stay in ICU with organic support, broad spectrum } \\
\text { antimicrobials, steroids, despite this poor } \\
\text { prognosis }\end{array}$ & $\begin{array}{l}\text { Stay in ICU with organic support, broad spectrum } \\
\text { antimicrobials, steroids, despite this poor prognosis }\end{array}$ \\
\hline
\end{tabular}

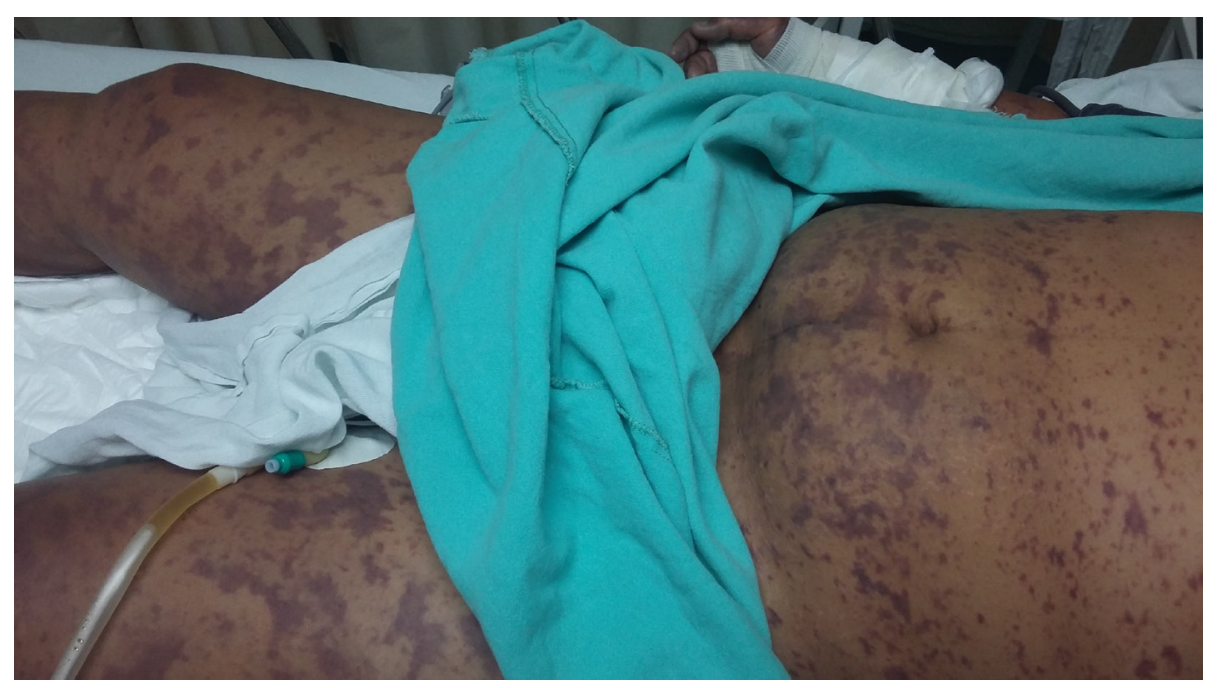

Figure 1: Case 1-Female, 24-years-old, with disseminated purpura and multiple organ failure; purpuric lesions are confluent and scattered macules of different sizes. 


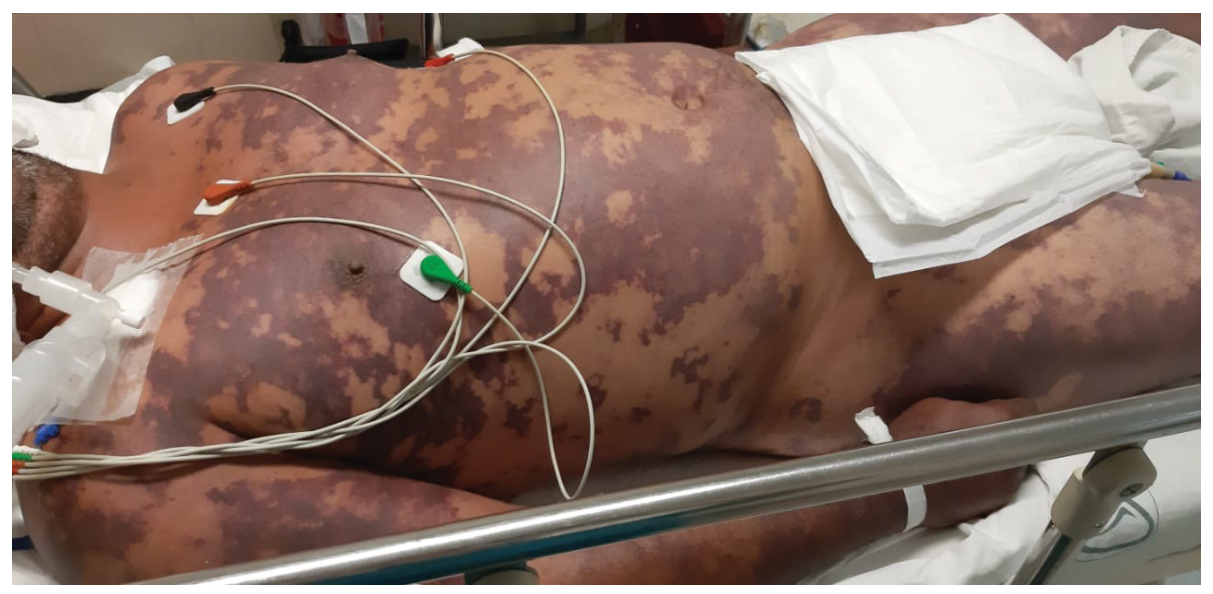

Figure 2: Case 2-Male, 42-years-old, with disseminated purpura and multiple organ failure; purpuric lesions are in extensive scattered patches.

dexamethasone can also be used, mainly in cases in which concomitant neuroinfection is documented.

Once these areas are covered, it is recommended to continue the indications of the campaign guidelines surviving sepsis for the management of septic critically ill patients.

Recently, cases of survivors have been reported, although with major sequelae, mainly of a neurological nature, who benefited from early therapies with continuous veno-venous hemodiafiltration and extracorporeal membrane oxygenation (ECMO), however these therapies are only available in centers highly specialized, often limited to a small number of patients [3,11-13].

Waterhouse Friderichsen Syndrome should be suspected in all patients with acute febrile syndrome, who appear critically ill (often encephalopathic, dehydrated or swollen, hyperdynamic, anuric or jaundiced), hypotensive or in shock, and with disseminated purpuric lesions, until proven otherwise.

Two cases are presented in young, apparently healthy patients, who presented with disseminated purpuric symptoms and multiple organ failure that led to death, confirming the presence of Waterhouse Friderichsen syndrome due to adrenal involvement (Table 1, Figure 1 and Figure 2).

\section{References}

1. Hata Y, Chiba T, Ohtani M, et al. (2015) An autopsy case of pneumococcal Waterhouse-Friderichsen syndrome with possible functional asplenia/hyposplenia. Int J Clin Exp Pathol 8: 75187525.

2. Ventura F, Bonsignore A, Portunato F, et al. (2013) A fatal case of streptococcal and meningococcal meningitis in a 2-years-old child occurring as Waterhouse-Friderichsen Syndrome. Journal of Forensic and Legal Medicine 20: 678-682.

3. Valverde G Cristián, Clavería R Cristián, Strassburger E Tanya, et al. (2001) Meningococcemia fulminante: Un problema no resuelto en pediatría. Revista chilena de pediatría 72: 12-18.

4. Shah VN (2013) Waterhouse-Friderichsen syndrome in an adult patient with meningococcal meningitis. Indian Journal of Dermatology 58: 161.

5. Shimizu S, Tahara Y, Atsumi T, et al. (2010) Waterhouse-friderichsen syndrome caused by invasive haemophilus influenzae type B infection in a previously healthy young man. Anaesth Intensive Care 38: 214-215.

6. Araújo Stanley de Almeida, Lana Ana Maria Arruda, Garcia Paula Piedade, et al. (2009) Puerperal septic shock due to $\beta$-hemolytic Streptococcus and Waterhouse-Friderichsen syndrome. Revista da Sociedade Brasileira de Medicina Tropical 42: 73-76.

7. Adem PV, Montgomery CP, Husain AN, et al. (2005) Staphylococcus aureus sepsis and the Waterhouse-Friderichsen syndrome in children. N Engl J Med 353: 1245-1251.

8. Angelski Carla L, McKay Eileen, Blackie Barbara (2011) A case of functional asplenia and pneumococcal sepsis. Pediatric Emergency Care 27: 639-641.

9. Vincentelli C, Molina EG, Robinson MJ (2009) Fatal pneumococcal Waterhouse-Friderichsen syndrome in a vaccinated adult with congenital asplenia. American Journal of Emergency Medicine 27: 751.e3-751.e5.

10. Hamilton D, Harris MD, Foweraker J, et al. (2004) Waterhouse-Friderichsen syndrome as a result of non-meningococcal infection. J Clin Pathol 57: 208-209.

11. Fernández-Rufete A, García-Vázquez E, Hernández-Torres A, et al. (2012) Bacteriemias por Staphylococcus coagulasa negativa: Análisis de factores pronóstico e influencia del tratamiento antibiótico. Rev Esp Quimioter 25: 199-205.

12. Predari Silvia Carla (2007) Estafilococos coagulasa negativos: El enemigo silente. Rev argent microbiol 39: 1-3.

13. Endo A, Shiraishi A, Aiboshi J, et al. (2014) A case of purpura fulminans caused by Hemophilus influenzae complicated by reversible cardiomyopathy. Journal of Intensive Care 2: 13.

Copyright: (c) 2020 Carpio-Orantes LD, et al. This is an open-access article distributed under the terms of the Creative Commons Attribution License, which permits unrestricted use, distribution, and reproduction in any medium, provided the original author and source are credited.

DOI: $10.36959 / 661 / 312$ 